\title{
PENGARUH HAFALAN AL-QUR'AN TERHADAP KEDISIPLINAN BELAJAR DAN PRESTASI BELAJAR PADA SISWA SD MUHAMMADIYAH SURONATAN YOGYAKARTA
}

\author{
Risnawati Pasaribu \\ Program Pasca Sarjana Magister Studi Islam \\ Universitas Muhammadiyah Yogyakarta \\ E-mail: risnawatipasaribu1@gmail.com
}

\begin{abstract}
Abstrak
Penelitian ini bertujuan: 1) mengetahui tingkat hafalan Al-Qur'an siswa, 2) mengetahui tingkat kedisiplinan belajar siswa, 3) mengetahui tingkat prestasi belajar siswa, 4) mengetahui pengaruh hafalan Al-Qur'an terhadap kedisiplinan belajar siswa, 5) mengetahui pengaruh hafalan Al-Qur'an terhadap prestasi belajar siswa, 6) mengetahui pengaruh kedisiplinan terhadap prestasi belajar siswa, 7) mengetahui pengaruh hafalan Al-Qur'an terhadap prestasi belajar siswa. Jenis penelitian ini penelitian kuantitatif. Populasi penelitian 220 siswa. Teknik sampling menggunakan proportional stratified random sampling. Jumlah sampel penelitian 150 siswa. Hasil penelitian ini, 1) tingkat hafalan Al-Qur'an dalam kategori sangat baik, 2) tingkat kedisiplinan belajar dalam kategori baik, 3) tingkat prestasi belajar dalam kategori sangat baik, 4) ada pengaruh signifikan hafalan Al-Qur'an terhadap kedisiplinan belajar, 5) ada pengaruh yang signifikan hafalan Al-Qur'an terhadap prestasi belajar, 6) ada pengaruh yang signifikan kedisiplinan belajar terhadap prestasi belajar, 7) pengaruh tidak langsung hafalan AlQuran terhadap prestasi belajar sebesar 0,121 lebih kecil dari pengaruh langsung sebesar 0,204 .
\end{abstract}

Kata kunci: hafalan al-quran, kedisiplinan belajar, dan prestasi belajar

\begin{abstract}
This study aims to: 1) know the level of rote Al-Qur'an students, 2) know the level of student learning discipline, 3) know the level of student learning achievement, 4) know the influence of memorization of Al-Qur'an on student learning discipline, 5) knowing the influence of Al-Qur'an memorization on student achievement, 6) know the influence of discipline on student achievement, 7) to know the influence of Al-Qur'an recitation on student achievement. This type of research is quantitative research. The study population is 220 students. The sampling technique uses proportional stratified random sampling. The sample size is 150 students. The results of this study, 1) the recitation level of the Qur'an in the category of very good, 2) the level of discipline learning in good category, 3) the level of learning achievement in the category very good, 4) there is significant influence of Qur'an recitation of discipline learning, 5) there is significant influence of Al-Qur'an recitation on learning achievement, 6) there is significant influence of learning discipline to learning achievement, 7) indirect influence of Al-Quran recitation to learning achievement of 0.121 less than the direct influence of 0.204.

Keywords: memorization of al-quran, discipline of learning, and learning achievement
\end{abstract}

Info Artikel

Diterima Februari 2018, disetujui Maret 2018, diterbitkan Juni 2018

Dipublikasikan Oleh: Program Studi Bimbingan dan Konseling Fakultas Keguruan dan Ilmu Pendidikan Universitas PGRI Yogyakarta 


\section{PENDAHULUAN}

Kualitas pendidikan di Indonesia masih dinilai memprihatinkan. Organisasi Kerja sama Ekonomi Pembangunan (OECD) pada tahun 2015 menerbitkan perolehan peringkat-peringkat tertinggi sekolahsekolah global. Indonesia, dari 76 negara, menempati posisi ke 69 atau urutan ke 8 paling bawah, sedangkan Singapura yang menjadi salah satu negara Asia yang mampu menempati posisi lima teratas. Ketika banyak negara Asia menjulang di daftar buatan OECD, peringkat Indonesia justru jatuh diurutaan 69, hanya unggul 7 peringkat dari Ghana yang ada dibawah. Dibandingakan Thailand yang berada diposisi 47, dan Malaysia berada diurutan 52 yang sama-sama berada dalam kawasan negara Asia. Adapun hasil studi PISA (Program for International Student Assessment) yang berfokus kepada studi literasi bacaan, Matematika, dan IPA, pada tahun 2015 menunjukkan Indonesia baru bisa menduduki peringkat 69 dari 76 negara.

Salah satu hal yang dapat digunakan untuk mengukur kualitas pendidikan adalah prestasi belajar. Prestasi belajar merupakan hasil penilaian pendidikan atas perkembangan dan kemajuan siswa dalam belajar. Prestasi menunjukkan hasil dari pelaksanaan kegiatan yang diikuti siswa di sekolah. Kegiatan belajar yang diikuti siswa dapat diukur melalui penguasaan materi yang diajarkan guru serta nilai-nilai yang terdapat dalam kurikulum.

Selain itu, amanah Undangundang Sistem Pendidikan Nasional tahun 2003 bermaksud agar pendidikan tidak hanya membentuk insan Indonesia yang cerdas, namun juga berkepribadian atau berkarakter. Sehingga, lahir generasi bangsa yang tumbuh dan berkembang dengan karakter yang bernapas nilai-nilai luhur bangsa serta agama. Pendidikan yang bertujuan melahirkan insan cerdas dan berkarakter kuat itu juga pernah ditegaskan oleh Martin Luther King, "intelegence plus character, that is the goal of true education" (kecerdasarkan yang berkarakter adalah tujuan akhir pendidikan yang sebenarnya). Salah satu karakter yang cukup penting dan mendukung prestasi belajar dan kesuksesan siswa di masa yang akan datang adalah kedisiplinan belajar.Kedisiplinan yang tinggi penting dimilikioleh setiap siswa karena dengandisiplin belajar yang tinggi akanmemudahkan siswa dalam belajarsecara terarah dan teratur. Siswa dengan disiplin belajar tinggi, akan akan selalu teratur dalam belajarnya, baik itu di rumah maupun di sekolah.

Meningkatkan prestasi dan kedisiplinan belajar tidaklah mudah. Sekolah harus kreatif dalam upaya meningkatkan prestasi dan kedisiplinan belajar. Salah satu hal yang bisa diterapkan adalah dengan menerapkan kebiasaan menghafal AlQur'an. Kegiatan menghafal Al- 
Qur'an, selain membiasakan siswa beperilaku disiplin, juga mendatangkan banyak manfaat lainnya. Para akademisi dan spesialis sependapat bahwa menghafal AlQur'an memiliki efek yang baik dalam pengembangan keterampilan dasar pada siswa, serta dapat meningkatkan pendidikan dan prestasi akademis. Dr. Abdullah Subaih, profesor psikologi di Universitas Imam Muhammad bin Su'ud al-Islamiyah di Riyadh, menyerukan kepada para pelajar agar mengikuti halaqoh-halaqoh menghafal Al-Qur'an. Ia juga menegaskan bahwa hafalan Al-Qur'an dapat membantu untuk konsentrasi dan merupakan syarat mendapatkan ilmu. Ia juga menambahkan bahwa semua ilmu pengetahuan, baik itu ilmu kedokteran, matematika, ilmu syariah, ilmu alam dan lain sebagainya, membutuhkan konsentrasi yang tinggi dalam meraihnya. Lebih lanjut dinyatakan bahwa sel-sel otak itu seperti halnya anggota tubuh lainnya, harus difungsikan terus. Orang yang terbiasa menghafal, maka sel-sel otak dan badannya aktif, dan menjadi lebih kuat dari orang yang mengabaikannya.

Dengan kita mengahafal alQuran akan berhubungan dengan kinerja otak. Sesuai dalam buku Ngalim Purwanto dalam Psikologi Pendidikan "jika sel-sel otak bekerja atau difungsikan terus menerus dengan hal yang postif dan aktif, maka akan menjadi lebih kuat". Begitu juga dengan anak-anak yang sudah terbiasa menghafal al-Quran, secara tidak langsung kinerja otaknya semakin tinggi dan membantu konsentrasi siswa. Ketika dia belajar mata pelajaran akademik di sekolah dan akan menghasilkan prestasi yang baik.

SD Muhammadiyah Suronatan Yogyakarta, merupakan salah satu sekolah dasar yang menerapkan kegiatan menghafal Al-Qur'an bagi siswanya, khususnya siswa kelas 4 sampai kelas 6. Mulai kelas 4, siswa dituntut untuk menghafal Al-Qur'an Juz 30. Sekolah tidak menentukan kapan waktunya siswa menyelesaikan hafalannya, tetapi yang penting adalah sebelum siswa lulus dari sekolah tersebut sudah harus hafal Al-Qur'an Juz 30. Seminggu dua kali sebelum jam pelajaran dimulai, dalam waktu 30 menit dilakukan hafalan secara bersama-sama di dalam kelas. Pada saat tersebut, siswa yang sudah hafal dapat "menyetorkan" hafalannya dengan cara membacakannya di depan guru.

SD Muhammadiyah Suronatan Yogyakarta juga merupakan sekolah dasar favorit yang mempunyai prestasi akademik yang baik di wilayah Yogyakarta. Hal ini dibuktikan dengan setiap tahun mendapatkan ranking yang tinggi dalam perolehan rata-rata Nilai Ebtanas Murni (NEM). Pada tahun pelajaran 2015/2016, SD Muhammadiyah Suronatan menempati ranking 2 tertinggi dalam perolehan NEM di Kota Yogyakarta. Selain itu, kedisiplinan belajar siswa juga relatif baik. Kasus-kasus ketidakdisiplinan siswa relatif sedikit. Kasus yaang 
paling banyak adalah ramai sendiri atau bercanda dengan teman ketika pelajaran sedang berlangsung. Namun, hal tersebut dapat diatasi guru dengan memberikan teguran secara baik.

Fenomena yang terjadi ini, menarik minat peneliti untuk melakukan penelitian, untuk menganalisis apakah kegiatan hafalan Al-Qur'an yang selama ini dilaksanakan oleh siswa kelas 4 sampai kelas 6 SD Muhammadiyah Suronatan Yogyakarta, menjadi faktor yang berpengaruh terhadap kedisiplinan dan prestasi belajar siswa.

\section{METODE PENELITIAN}

\section{Jenis Penelitian}

Penelitian ini merupakan penelitian survei, yaitu penelitian yang mengumpulkan informasi dari suatu sampel dengan menanyakan melalui angket atau interview, agar nantinya menggambarkan sebagai aspek dari populasi. Berdasarkan pendekatan, maka penelitian merupakan penelitian kuantitatif

\section{Populasi dan Sample Penelitian}

Populasi adalah jumlah total dari seluruh unit atau elemen di mana penyelidik tertarik. Populasi dapat berupa organisme, orang atau kelompok orang, masyarakat, organisasi, benda, objek, peristiwa, peristiwa, atau laporan yang semuanya memiliki ciri dan harus didefinisikan secara spesifik dan tidak secara mendua. Populasi dalam penelitian ini adalah siswa kelas 4, 5, dan 6 SD
Muhammadiyah Suronatan sejumlah 220 siswa.

Jumlah sampel penelitian sejumlah 150 responden. Teknik sampling yang digunakan adalah proportional stratified random sampling. Teknik ini disebut juga teknik sampling berlapis atau berjenjang.

\section{Teknik pengumpulan Data}

Teknik pengumpulan data yang dipergunakan dalam penelitian ini adalah sebagai berikut:

1. Kuesioner. Kuesioner digunakan untuk mengumpulkan data kedisiplinan belajar.

2. Dokumentasi

Dokumentasi dalam penelitian ini dipergunakan untuk pengumpulan data menghafal al Qur'an dan prestasi belajar.Data prestasi belajar dilihat dari hasil rapor semester genap tahun pelajaran 2016/2017. Adapun data hafalan Al-Qur'an diambil dari dokumentasi jumlah surat dalam juz 30 yang mampu dihafal siswa.

\section{Instrument Penelitian}

Instrumen dalam penelitian ini adalah kuesioner. Kuesioner dalam penelitian digunakan untuk mengukur kedisiplinan belajar. Kisi-kisi Kuesioner Kedisiplinan Belajar dapat dideskripsikan dalam tabel sebagai berikut: 
Tabel 1

Kisi-kisi Kedisiplinan Belajar

\begin{tabular}{|l|l|c|c|}
\hline \multirow{2}{*}{ No. } & \multicolumn{1}{|c|}{ Indikator } & Jumlah Item & \multicolumn{1}{c|}{ Item Ke- } \\
\hline \multirow{4}{*}{1.} & Disiplin Waktu & & \\
\cline { 2 - 4 } & Tepat waktu dalam belajar & 4 & $1,2,3,4$ \\
\cline { 2 - 4 } & Tidak meninggalkan kelas/membolos saat pelajaran. & 4 & $5,6,7,8$ \\
\cline { 2 - 4 } & Menyelesaikan tugas sesuai waktu yang ditetapkan. & 4 & $9,10,11,12$ \\
\hline \multirow{4}{*}{2.} & Disiplin Perbuatan & & \\
\cline { 2 - 4 } & Patuh dan tidak menentang peraturan yang berlaku. & 4 & $13,14,15,16$ \\
\cline { 2 - 4 } & Tidak malas belajar. & 4 & $17,18,19,20$ \\
\cline { 2 - 4 } & Tidak menyuruh orang lain bekerja demi dirinya. & 4 & $21,22,23,24$ \\
\cline { 2 - 4 } & Tidak suka berbohong. & 4 & $25,26,27,28$ \\
\cline { 2 - 4 } & Tingkah laku menyenangkan. & 4 & $29,30,31,32$ \\
\hline \multicolumn{2}{|c|}{ Jumlah } & $\mathbf{3 2}$ & \\
\hline
\end{tabular}

Uji Validitas dan Reliabilitas Instrumen

Metode yang digunakan untuk mencari validitas instrumen adalah korelasi product moment (person correlation) antara skor setiap butir pertanyaan dengan skor total sehingga sering disebut sebagai inter item total correlation.

Batas kritis untuk pengujian validitas dalam penelitian digunakan adalah 0,3. Apabila koefisien validitas kurang dari 0,30 biasanya dianggap sebagai tidak memuaskan.

Dari 32 item pertanyaaan dalam instrumen kedisiplinan belajar, terdapat 12 item yang tidak valid, yaitu item nomor $4,6,7,10,15,16$, 18, 20, 23, 26, 30, dan 32. Item tersebut didrop dan tidak diikutkan dalam pengambilan data penelitian. Berdasarkan hal tersebut, maka jumlah item pertanyaan dalam instrumen kedisiplinan belajar yang dipergunakan untuk pengambilan data penelitian sejumlah 20 item. Pengujian reliabilitas dalam penelitian ini dilakukan dengan menggunakan rumus Cronbach's Alpha.

Hasil pengujian reliabilitas instrumen kedisiplinan belajar didapatkan nilai Cronbach Alpha sebesar 0,833. Berdasrkan nilai Cronbach Alpha yang lebih dari 0,7, disimpulkan bahwa instrumen kedisiplinan belajar reliabel.

\section{Teknik Analisis Data}

\section{Analisis Deskriptif}

Data hafalan Al-Qur'an dan kedisiplinan belajar ditafsirkan dengan lima kategori. Rentang data untuk lima kategori dengan konsep kurva normal. Nilai $\sigma$ (standar deviasi teoritis) dihitung dari rentang skor dibagi 6. Adapun nilai $\sigma$ (mean teoritis) dihitung dari (rentang skor : 2) + skor minimal. 
Tabel 2.

Kaidah Interpretasi Prestasi Belajar

\begin{tabular}{|ll|l|l|}
\hline Angka & Huruf & Predikat \\
\hline $8-10=80-100$ & $\mathrm{~A}$ & Sangat Baik \\
\hline $7-7,9=70-79$ & $\mathrm{~B}$ & Baik \\
\hline $6-6,9=60-69$ & $\mathrm{C}$ & Cukup \\
\hline $5-5,9=50-59$ & $\mathrm{D}$ & Kurang \\
\hline $0-4,9=0-49$ & $\mathrm{E}$ & Gagal \\
\hline
\end{tabular}

\section{Uji Asumsi Structural Equation Model (SEM)}

Analisis data dalam penelitian ini digunakan Structural Equation Model (SEM). Sebelum dilakukan analisis data, terlebih dahulu dilakukan uji asumsi SEM, yaitu meliputi:

\section{Ukuran Sampel}

Ukuran sampel penelitian untuk pengajuan model dengan menggunakan SEM adalah antara 100200 sampel atau tergantung pada jumlah parameter yang diesrimasi, yaitu jumlah indikator dikalikan 5 sampai 10.

\section{Outliers}

\section{Univariate Outliers}

Outliers adalah skor yang berbeda dari yang lainnya. Sebuah kasus dapat memiliki univariat outlier jika ekstrem pada satu variabel. univariat outlier mudah ditemukan dengan memeriksa distribusi frekuensi skor $\mathrm{z}$ (misalnya, | $\mathrm{z} \quad \mid>3,00$ mengindikasikan outlier).

\section{Mutivariate Outliers}

\section{Deteksi multivariat outlier} didasarkan pada statistik jarak Mahalanobis (D), yang menunjukkan jarak pada unit deviasi standar antara seperangkat nilai (vektor) untuk kasus individual dan mean sampel untuk semua variabel (centroid), mengoreksi interkorelasi. Dalam sampel besar dengan distribusi normal, D2 didistribusikan sebagai statistik chisquare $\left(\chi^{2}\right)$ dengan tingkat kebebasan sama dengan jumlah variabel. Nilai D2 dengan nilai $\mathrm{p}$ rendah pada distribusi $\chi^{2}$ yang sesuai dapat menyebabkan penolakan hipotesis nol bahwa kasus tersebut berasal dari populasi yang sama dengan yang lainnya. Tingkat signifikansi statistik konservatif biasanya direkomendasikan untuk tes ini (misalnya, $\mathrm{p}<.001$ ).

\section{Normalitas}

Uji normalitas dapat dilakukan secara univariat maupun secara multivariat. Normalitas data merupakan persyaratan digunakannya teknik statistik parametrik. Berdasarkan teknik analisis yang digunakan dalam menguji hipotesis dalam penelitian ini, yaitu korelasi product moment dan regresi termasuk bagian dari statistik parametrik, maka dilakukan pengujian normalitas data sebagai persyaratan analisis. Uji normalitas dilakukan dengan mengamati nilai skewness dari data yang digunakan.Data dikatakan berdistribusi normal apabila 
didapatkan nilai-z yang kurang dari nilai z-tabel pada taraf signifikansi $1 \%$ sebesar $+2,58$.

\section{Multikolieritas}

Pengujian multikolinieritas bertujuan untuk menguji apakah model regresi ditemukan adanya korelasi antar variabel bebas (independen). Pengujian multikolinieritas dilakukan dengan melihat nilai determinant of sample covariance matrix. Determinan yang benar-benar kecil dan mendekati nol mengindikasikan adanya multikolinieritas.

Analisis Structural Equation Model (SEM)

Tabel 3

Kriteria Goodness of Fit

\begin{tabular}{lc}
\hline \multicolumn{1}{c}{ Goodness of Fit Indexs } & Cut off Value \\
\hline Chi-Square & Diharapkan kecil \\
Significancy probability & $\geq 0,05$ \\
CMIN/DF & $\leq 2,00$ \\
RMSEA & $\leq 0,08$ \\
GFI & $\geq 0,90$ \\
AGFI & $\geq 0,90$ \\
TLI & $\geq 0,95$ \\
CFI & $\geq 0,95$ \\
\hline
\end{tabular}

\section{Landasan Teori}

\section{Hafalan Al-Qur'an}

Hafalan berasal dari kata dasar "hafal" yang berarti dapat mengingat di luar kepala. Tahfiz berasal dari

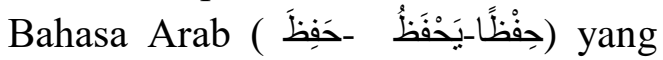
berarti menghafal, sedangkan kata "menghafal" berasal dari kata "hafal" yang memiliki dua arti : (1) telah masuk dalam ingatan (tentang pelajaran), dan (2) dapat mengucapkan di luar kepala (tanpa melihat buku atau catatan lain). Adapun arti "menghafal" adalah berusaha meresapkan ke dalam pikiran agar selalu ingat.
Al-Qur'an ( نآرقل ) berasal dari bahasa Arab dari kata kerja (fi'il) yang artinya adalah membaca. Al-Qur'an adalah sebuah kitab yang teratur tata cara membacanya, mana yang dipendekkan, dipanjangkan, dipertebal, atau diperluas ucapannya, di mana tempat yang terlarang atau yang boleh, atau yang harus memulai dan berhenti, bahkan diatur lagu dan iramanya, sampai kepada etika membacanya.

Sedangkan dalam teori psikologi bahwa Richards dan Platt berkenaan dengan menghafal (memorizing) menyatakan sebagai berikut:

"Memorizing is the process of 
establishing information in memory. The term 'memorizing' usually refers to the conscious processes. This means the learners use memorization consciously and they think about the process of memorization when they are applying it".

Menghafal adalah proses pembentukan informasi dalam memori. Istilah 'menghafal' biasanya mengacu pada proses sadar. Ini berarti peserta didik menggunakan menghafal secara sadar dan mereka berpikir tentang proses menghafal ketika mereka menerapkannya. Memorizing is learning by heart the relation between a word and its meaning. Menghafal adalah belajar dengan perasaan hubungan antara kata dan maknanya. (menghafal Qur'an adalah bunyi/suara dan panjang pendek dll).

\section{Kedisiplinan Belajar}

Menurut Drs. Syaiful Bahri Djamarah disiplin belajar adalah belajar dengan teratur yang merupakan pedoman mutlak dan tidak bisa diabaikan oleh seseorang yang menuntut ilmu di sekolah ataupun di pondok pesantren. Hal ini dikarenakan disiplin belajar dapat melahirkan semangat menghargai waktu untuk terus belajar, bukan menyia-nyiakan waktu berlalu tanpa manfaat apapun. Budaya menunda-nunda waktu ataupun budaya jam karet adalah musuh besar bagi mereka yang mengagungkan disiplin dalam belajar. Sehingga jadwal dan peraturan atau tata tertib belajar yang telah disusun secara sadar mereka taati dengan ikhlas dan penuh tanggung jawab.

Pada penelitian ini, indikator yang digunakan untuk mengukur kedisiplinan belajar adalah pendapat dari Moenir yaitu:

1. Disiplin Waktu, meliputi:

a. Tepat waktu dalam belajar, mencakup datang dan pulang sekolah tepat waktu, mulai dari selesai belajar di rumah dan di sekolah tepat waktu

b. Tidak meninggalkan kelas/membolos saat pelajaran.

c. Menyelesaikan tugas sesuai waktu yang ditetapkan.

2. Disiplin Perbuatan, meliputi:

a. Patuh dan tidak menentang peraturan yang berlaku.

b. Tidak malas belajar.

c. Tidak menyuruh orang lain bekerja demi dirinya.

d. Tidak suka berbohong.

e. Tingkah laku menyenangkan, mencakup tidak mencontek, tidak membuat keributan, dan tidak mengganggu orang lain yang sedang belajar.

3. Prestasi Belajar

Menurut Tulus Tu'u, prestasi belajar adalah hasil yang dicapai seseorang ketika mengerjakan tugas atau kegiatan tertentu. Adapun menurut Asep Jihad dan Abdul Haris, prestasi belajar adalah pencapaian bentuk perubahan perilaku yang cenderung menetap dari ranah kognitif, afektif, dan psikomotor 
dari proses belajar yang dilakukan dalam waktu tertentu.

\section{HASIL DAN PEMBAHASAN \\ Hasil Penelitian \\ Hafalan Al-Quran}

Hafalan Al-Qur'an merupakan hafalan surat-surat dalam juz 30, dan diperoleh dari dokumentasi hafalan Al-Qur'an. Hasil penelitian didapatkan nilai hafalan Al-Qur'an terendah adalah 26 dan tertinggi 37, dengan rata-rata sebesar 32,1667, dan standar deviasi sebesar 3,13117. Nilai median didapatkan sebesar 32 dan modus sebesar 33 .

Hasil penelitian menunjukkan bahwa sebagian besar responden mempunyai hafalan Al-Qur'an kategori sangat baik, yaitu 138 responden $(92,00 \%)$. Hal ini didukung dengan nilai rata-rata skor hafalan AlQur'an sebesar 32,1667, sehingga dapat diinterpretasikan bahwa hafalan Al-Qur'an siswa SD Muhammadiyah Suronatan Yogyakarta, termasuk dalam kategori yang sangat baik.

\section{Kedisiplinan Belajar}

Kedisiplinan belajar diperoleh dari penyebaran kuesioner. Hasil penelitian didapatkan skor kedisiplinan terendah sebesar 58 dan tertinggi sebesar 94, dengan rata-rata sebesar 75,0733 dan standar deviasi sebesar 9,50528. Nilai median didapatkan sebesar 76 dan modus sebesar 77 .

Hasil penelitian didapatkan sebagian besar responden mempunyai kedisiplinan belajar kategori baik, yaitu 66 responden $(44,00 \%)$. Hal ini didukung dengan nilai rata-rata skor kedisiplinan belajar sebesar 75,0733, sehingga dapat diinterpretasikan bahwa kedisiplinan belajar siswa SD Muhammadiyah Suronatan Yogyakarta, termasuk dalam kategori yang baik.

\section{Prestasi Belajar}

Prestasi belajar diperoleh dari dokumentasi rata-rata nilai rapor. Hasil penelitian didapatkan nilai prestasi belajar terendah sebesar 75,5 dan tertinggi sebesar 96,2, dengan rata-rata sebesar 86,594 dan standar deviasi sebesar 4,0233. Nilai median didapatkan sebesar 87,245 dan modus sebesar 87,4.

Hasil penelitiandidapatakan sebagian besar responden mempunyai prestasi belajar kategori sangat baik, yaitu 141 responden $(94,00 \%)$. Hal ini didukung dengan nilai rata-rata prestasi belajar sebesar 86,594, sehingga dapat diinterpretasikan bahwa prestasi belajar siswa SD Muhammadiyah Suronatan Yogyakarta, termasuk dalam kategori yang sangat baik.

\section{Uji Asumsi Structural Equation Model (SEM) Jumlah Sampel}

Jumlah sampel dalam penelitian ini adalah 150 responden. Hal ini berarti telah memenuhi ukuran sampel untuk model SEM, yaitu antara 100200 sampel. Apabila dilihat dari 
jumlah observed variabel sejumlah 22, maka jumlah sampel sudah melebihi jumlah minimal sampel yaitu $22 \times 5=$ 110 responden.

\section{Uji Outliers}

Dari hasil yang didapatkan bahwa nilai mutlak skor Z, tidak ada yang melebihi 3, sehingga disimpulkan bahwa secara univariat untuk semua variabel, tidak ada data yang outliers. Berdasarkan hasil yang diperoleh maka tidak ada data penelitian yang memiliki nilai $\mathrm{p}<$ 0,01 , sehingga disimpulkan bahwa secara multivariat tidak ada data yang outliers.

\section{Uji Normalitas}

Dari hasil yang di dapat bahwa semua nilai c.r untuk skewness berada diantara rentang antara $+2,58$ pada tingkat signifikansi 0.01, sehingga disimpulkan bahwa secara univariat semua variabel berdistribusi normal. Nilai c.r. Kurtosis Multivariat Mardia didapatkan 1,717 atau kurang dari 2,58, sehingga disimpulkan bahwa secara multivariat model penelitian berdistribusi normal.

\section{Uji Multikolinieritas \\ Singularitas}

dan

Berdasarkan

hasil

analisis,didapatkan determinant of sample covariance matrix pada penelitian ini adalah 0,000 , sehingga terdapat multikolinearitas dan singularitas pada model SEM. Namun demikian menurut Bahri dan Zamzam, data masih dapat digunakan apabila uji asumsi SEM yang lain terpenuhi.

\section{Uji Structural Equation Model (SEM)}

Structural Equation Modelling adalah pendekatan statistik untuk menguji hipotesis tentang hubungan antara variabel yang diamati dan laten. Variabel yang diamati juga disebut variabel indikator atau variabel manifes. Variabel laten juga menunjukkan variabel atau faktor yang tidak teramati. Model full dalam penelitian ini dapat digambarkan sebagai berikut:

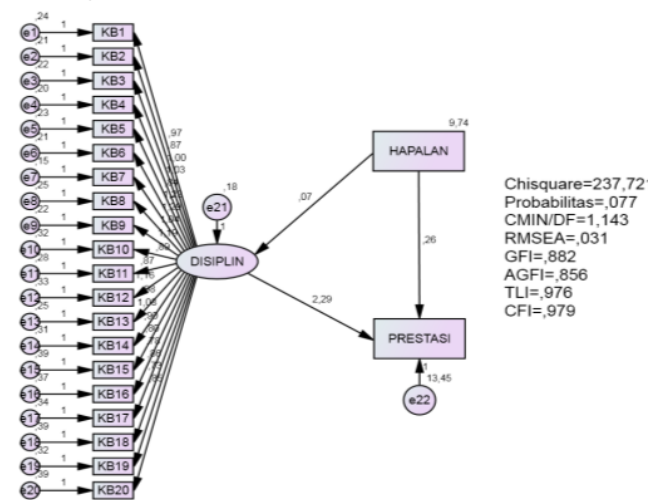

Gambar 1

\section{Model Full dalam Penelitian}

Dari hasil yang didapatkan bahwa terdapat 5 (lima) parameter Goodness of Fit Indexs yang hasilnya di atas nilai cut off value, yaitu probability, CMIN/DF, RMSEA, TLI, dan CFI. Berdasarkan hal tersebut model SEM fit dan dapat dipergunakan untuk analisis lebih lanjut. 


\section{Uji Hipotesis}

Berdasarkan tabel di atas, dilakukan pengujian hipotesis sebagai berikut :

1. Uji Hipotesis Pertama

Hipotesis pertama pada penelitian ini adalah ada pengaruh hafalan Al-Qur'an terhadap kedisiplinan belajar siswa SD Muhammadiyah Suronatan Yogyakarta. Berdasarkan hasil analisis didapatkan nilai $\mathrm{CR}$ sebesar 5,334 dan p sebesar 0,000. Berdasarkan nilai $\mathrm{p}<0,05$, maka disimpulkan ada pengaruh yang signifikan hafalan Al-Qur'an terhadap kedisiplinan belajar siswa SD Muhammadiyah Suronatan Yogyakarta, sehingga hipotesis pertama (Ha1) dalam penelitian ini diterima.

2. Uji Hipotesis Kedua

Hipotesis kedua pada penelitian ini adalah ada pengaruh hafalan Al-Qur'an terhadap prestasi belajar siswa SD Muhammadiyah

SuronatanYogyakarta.

Berdasarkan hasil analisis didapatkan nilai $\mathrm{CR}$ sebesar 2,410 dan p sebesar 0,016. Berdasarkan nilai $\mathrm{p}<0,05$, maka disimpulkan ada pengaruh yang signifikan hafalan Al-Qur'an terhadap prestasi belajar siswa SD Muhammadiyah Suronatan Yogyakarta, sehingga sehingga hipotesis kedua (Ha2) dalam penelitian ini diterima.
3. Uji Hipotesis Ketiga

Hipotesis ketiga pada penelitian ini adalah ada pengaruh kedisiplinan belajar dengan prestasi belajar siswa SD Muhammadiyah Suronatan Yogyakarta. Berdasarkan hasil analisis didapatkan nilai CR sebesar 3,002dan p sebesar 0,003. Berdasarkan nilai $\mathrm{p}<0,05$, maka disimpulkan ada pengaruh yang signifikan kedisiplinan belajar dengan prestasi belajar siswa SD Muhammadiyah Suronatan Yogyakarta, sehingga sehingga hipotesis ketiga (Ha3) dalam penelitian ini diterima.

4. Uji Hipotesis Keempat

Hipotesis keempat pada penelitian ini adalah pengaruh hafalan Al-Qur'an terhadap prestasi belajar merupakan pengaruh tidak langsung dengan melalui kedisiplinan belajar sebagai variabel antara. Apabila melihat hasil analisis jalur, didapatkan pengaruh tidak langsung (standardized indirect effect) sebesar 0,121 lebih kecil dari pengaruh langsung (standardized direct effect) sebesar 0,204. Hal ini menunjukkan bahwa pengaruh hafalan Al-Qur'an terhadap prestasi belajar siswa SD Muhammadiyah Suronatan Yogyakarta, merupakan pengaruh langsung, sehingga hipotesis keempat (Ha4) dalam penelitian ini ditolak. 


\section{PEMBAHASAN}

Hasil penelitian menunjukkan bahwa tingkat hafalan Al-Qur'an siswa SD Muhammadiyah Suronatan Yogyakarta, termasuk dalam kategori sangat baik. Hasil penelitian menunjukkan bahwa tingkat kedisiplinan belajar siswa SD Muhammadiyah Suronatan Yogyakarta, termasuk dalam kategori baik. Hasil penelitian menunjukkan bahwa tingkat prestasi belajar siswa SD Muhammadiyah Suronatan Yogyakarta, termasuk dalam kategori sangat baik. Salah satu hal yang mempengaruhi prestasi belajar adalah lingkungan sosial di sekolah. Lingkungan sosial ini meliputi para guru, para tenaga kependidikan (kepala sekolah dan wakil-wakilnya) dan teman-teman sekelas.

Hasil penelitian menunjukkan bahwa ada pengaruh yang signifikan hafalan Al-Qur'an terhadap kedisiplinan belajar siswa SD Muhammadiyah Suronatan Yogyakarta. Upayauntuk membentuk kedisiplinan belajar adalah dengan membiasakan sebuah perilaku yang positif, salah satunya adalah kebiasaan menghafal Al-Qur'an.

Hasil penelitian menunjukkan bahwa ada pengaruh yang signifikan hafalan Al-Qur'an terhadap prestasi belajar siswa SD Muhammadiyah Suronatan Yogyakarta. Hasil penelitian ini mendukung penelitian Ahmad Agus Sofwan (2011); dan Husna Rosidah (2015). Hal ini karena kegiatan menghafal Al-Qur'an membutuhkan konsentrasi yang tinggi, sehingga secara tidak langsung akan melatih dalam berkonsentrasi. Siswa yang sering menghafal Al-Qur'an secara tidak langsung melatih konsentrasi secara rutin. Konsentrasi yang tinggi akan membantu siswa dalam memahami materi pelajaran. Hal ini menyebabkan prestasi belajarnya juga menjadi tinggi.

Hasil penelitian menunjukkan bahwa ada pengaruh yang signifikan kedisiplinan belajar terhadap prestasi belajar siswa SD Muhammadiyah Suronatan Yogyakarta. Hasil penelitian ini mendukung hasil penelitian Nisa Dian Rachmawati \& Wahyudin Noe (2014) dan penelitian Bambang Sumantri (2010).

Hasil penelitian menunjukkan bahwa pengaruh hafalan Al-Qur'an terhadap prestasi belajar siswa SD Muhammadiyah Suronatan Yogyakarta, merupakan pengaruh langsung. Hal ini disebabkan karena, metode menghafalkan Al-Qur'an yang dilakukan secara terus menerus dan diulang-ulang, dapat mempengaruhi metodenya dalam belajar mata pelajaran yang lain. Selain itu, proses menghafal Al-Qur'an juga menjadi latihan siswa untuk berkonsentrasi. Pengulangan dengan frekuensi yang sering dan dilakukan pada konsentrasi yang tinggi, menyebabkan siswa mampu untuk memahami mata pelajaran yang diajarkan guru. Hal ini berpengaruh terhadap meningkatkan prestasi belajar siswa. 


\section{KESIMPULAN \\ REKOMENDASI \\ Kesimpulan}

Berdasarkan hasil penelitian dan pembahasan, maka dapat ditarik kesimpulan sebagai berikut:

1. Tingkat hafalan Al-Qur'an siswa SD Muhammadiyah Suronatan Yogyakarta, termasuk dalam kategori sangat baik.

2. Tingkat kedisiplinan belajar siswa SD Muhammadiyah Suronatan Yogyakarta, termasuk dalam kategori baik.

3. Tingkat prestasi belajar siswa SD Muhammadiyah Suronatan Yogyakarta, termasuk dalam kategori sangat baik.

4. Ada pengaruh yang signifikan hafalan Al-Qur'an terhadap kedisiplinan belajar siswa SD Muhammadiyah Suronatan Yogyakarta.

5. Ada pengaruh yang signifikan hafalan Al-Qur'an terhadap prestasi belajar siswa SD Muhammadiyah Suronatan Yogyakarta.

6. Ada pengaruh yang signifikan kedisiplinan belajar terhadap prestasi belajar siswa SD Muhammadiyah Suronatan Yogyakarta.

7. Pengaruh hafalan Al-Qur'an terhadap prestasi belajar siswa SD Muhammadiyah Suronatan Yogyakarta, merupakan pengaruh langsung atau sebagai variabel yang paling dominan. Dapat kita lihat pada hasil uji analisis jalur di tabel 16, pengaruh tidak langsung hafalan al-Quran terhadap Prestasi belajar sebesar 0,121 lebih kecil dari pengaruh langsung hafalan al-Quran terhadap prestasi belajar sebesar 0,204.

\section{Rekomendasi}

1. Bagi Siswa

Hendaknya siswa dapat terus memperbaiki dan menambah hafalan Al-Qur'an setiap hari, dan bahkan apabila siswa sudah lulus dari SD Muhammadiyah Suronatan.

2. Bagi Manajemen SD Muhammadiyah Suronatan

Hendaknya dapat bekerja sama dengan orang tua untuk memantau kegiatan menghafal AlQur'an di rumah. Hal ini diharapkan akan mempercepat proses menghafal Al-Qur'an, sehingga target hafalan di SD Muhammadiyah Suronatan dapat terus ditingkatkan. Hal ini diharapkan selain dapat meningkatkan kedisiplinan, juga dapat meningkatkan prestasi belajar siswa.

3. Bagi Seluruh pihak sekolah SD, SMP, SMA diharapkan bisa menerapkan hafalan al-Quran setiap sekolah masing-masing untuk meningkatkan kedisiplinan dan prestasi yang baik.

4. Bagi Penelitian Terdahulu Hendaknya dapat melakukan penelitian mengenai kedisiplinan dan prestasi belajar, dengan 
mengambil variabel yang mempengaruhinya selain hafalan al Qur'an. Hal ini diharapkan dapat mengidentifikasi variabel apa saja yang berpengaruh terhadap kedisiplinan dan prestasi belajar.

\section{DAFTAR PUSTAKA}

Asmani, Jamal Ma'mur. 2011. Buku Panduan Internalisasi Pendidikan Karakter di Sekolah. Yogyakarta: DIVA Press.

Azwar, Saifuddin. 2012. Penyusunan Skala Psikologi. Yogyakarta: Pustaka Pelajar.

Bahri, S., \& Zamzam, S. 2014. Model Penelitian Kuantitatif Berbasis SEM-AMOS. Yogyakarta: Deepublish.

Ferdinand, Augusty. 2002. Structural Equation Modeling dalam Penelitian Manajemen: Aplikasi Model-model Rumit dalam Penelitian untuk Tesis Magister dan Disertasi Doktor. Semarang : BP Undip.

Ghozali, Imam. 2014. Model Persamaan Struktural: Konsep dan Aplikasi Dengan Program AMOS 22.0. Semarang : Badan Penerbit Universitas Diponegoro.

Idrus, M. 2009. Metode Penelitian Ilmu Sosial Pendekatan Kualitatif dan Kuantitatif. Jakarta: Erlangga.
Jihad, Asep dan Haris, Abdul. 2008. Evaluasi Pembelajaran. Yogyakarta: Multi Pressindo.

Moenir, 2010. Masalah-Masalah dalam Belajar. Yogyakarta: Pustaka Pelajar.

Mondria, De-Vries. "Efficiently Memorizing Words With The Help Of Word Cards And "Hand Computer": Theory And Applications". Journal of System. Vo. 22. No. 2.

Munawwir, Ahmad Warson. 1997. AlMunawwir: Kamus ArabIndonesia terlengkap. Surabaya: Pustaka Progresif.

Oanh, D. T. H., \& Hien, N. T. 2006."Memorization and EFL Students' Strategies atUniversity Level in Vietnam", Teaching English as a Second or Foreign Language, Vol. 10, No. 22, September.

Poerwadarminta. 2002. Kamus Besar Bahasa Indonesia. Jakarta: Duta Rakyat.

Rachmawati, N. D., \& Noe, W. "Hubungan Disiplin Belajar dengan Hasil Belajar Siswa Pada Mata Pelajaran PKn di Sekolah Dasar Negeri Sumber Jaya 04 Tambun Selatan Kabupaten Bekasi”. Jurnal Pedagogik, II (2), September 2014.

Rosidah, Husna. 2015. Pengaruh Kemampuan Menghafal AlQur'an Terhadap Prestasi Belajar Bahasa Arab Siswa Tahfidz Mts YAPI Pakem 
Sleman Yogyakarta Ditinjau dari Perspektif Teori Behaviorisme. Skripsi Program Studi Pendidikan Bahasa Arah Universitas Islam Negeri Sunan Kalijaga.

Sarnapi. 2016. Peringkat Pendidikan Indonesia Masih Rendah. dalam http://www.pikiranrakyat.com/pendidikan/2016/06/ 18/peringkat-pendidikanindonesia-masih-rendah-372187, diakses tanggal 1 Februari 2017.

Silalahi, U. 2009. Metode Penelitian Sosial. Jakarta : PT. Refika Aditama.

Suharso \& Retnoningsih, A. 2011. Kamus Bahasa Indonesia Lengkap. Semarang; Widya Karya.

Sumantri B. 2010. Pengaruh Disiplin Belajar Terhadap Prestasi Belajar Siswa Kelas XI SMK PGRI 4 Ngawi Tahun Pelajaran 2009/2010, Jurnal Media Prestasi, Vol.. VI No. 3 Edisi Desember 2010Syaiful Bahri Djamarah, 2002. Rahasia Sukses Belajar. Jakarta: Rineka Cipta.

Tri Pratini. 2016. “Terpuruknya Kualitas Pendidikan di Indonesia". dalam http://www.kompasiana.com/trip ratini3/terpuruknya-kualitaspendidikan-diindonesia56f0ddcc $7097739808 \mathrm{c}$ 6b62a, diakses tanggal 1 Februari 2017.
Tu'u,T. 2004. Peran Disiplin Pada Perilaku dan Prestasi Siswa. Jakarta: Grasindo.

Usman, H., dan Akbar, P. S. 2009. Metodologi Penelitian Sosial. Jakarta: Bumi Aksara.

Zuriah, Nurul. 2009. Metodologi Penelitian Sosial dan Pendidikan: Teori - Aplikasi. Jakarta : Bumi Aksara. 